\title{
Lactation performance and amino acid utilization of cows fed increasing amounts of reduced-fat dried distillers grains with solubles ${ }^{1}$
}

\author{
K. Mjoun, ${ }^{*}$ K. F. Kalscheur, ${ }^{* 2}$ A. R. Hippen, ${ }^{*}$ D. J. Schingoethe, ${ }^{*}$ and D. E. Little† \\ *Dairy Science Department, South Dakota State University, Brookings 57007 \\ †DairyNet Inc., Brookings, SD 57006
}

\begin{abstract}
The use of a solvent-extraction process that removes corn oil from distillers grains produces a reduced-fat coproduct (RFDG). To determine the optimal concentration of RFDG in mid-lactation diets, 22 multiparous and 19 primiparous Holstein cows were used in a completely randomized design for $8 \mathrm{wk}$, including a 2 -wk covariate period. The RFDG was included at 0, 10, 20, and $30 \%$ of the diet on a dry matter basis, replacing soybean feedstuffs. Increasing RFDG in diets had no effect on dry matter intake $(23.1 \mathrm{~kg} / \mathrm{d})$ or milk production $(35.0$ $\mathrm{kg} / \mathrm{d}$ ). Milk fat percentage increased linearly from 3.18 to $3.72 \%$ as RFDG increased from 0 to $30 \%$ of the diet. Similarly, milk fat yield tended to increase linearly from 1.08 to $1.32 \mathrm{~kg} / \mathrm{d}$. Milk protein percentage $(2.99,3.06$, 3.13 , and $2.99 \%$ for diets with RFDG from 0 to $30 \%$ ) responded quadratically, whereas protein yield was not affected by treatment. Milk urea $\mathrm{N}$ decreased linearly from 15.8 to $13.1 \mathrm{mg} / \mathrm{dL}$. The efficiency of $\mathrm{N}$ utilization for milk production was not affected by including RFDG (26.1\%), whereas the efficiency of milk production (energy-corrected milk divided by dry matter intake) tended to increase linearly with increasing RFDG in the diet. Similarly, concentrations of plasma glucose increased linearly. Arterial Lys decreased linearly from 66.0 to $44.8 \mu \mathrm{M} / \mathrm{L}$, whereas arterial Met increased linearly from 16.5 to $29.3 \mu \mathrm{M} / \mathrm{L}$. Arteriovenous difference of Lys decreased linearly from 42.6 to $32.5 \mu \mathrm{M} / \mathrm{L}$, whereas that of Met was unaffected. The extraction of Lys by the mammary gland increased linearly from 64.3 to $72.2 \%$, whereas that of Met decreased linearly from 71.6 to $42.7 \%$. Feeding up to $30 \%$ of RFDG in a mid-lactation diet supported lactation performance similarly to cows fed the soybean protein-based diet (0\% RFDG).
\end{abstract}

\footnotetext{
Received May 12, 2009.

Accepted September 24, 2009.

${ }^{1}$ Publication 3637 of the South Dakota Agricultural Experiment Station Journal Series.

${ }^{2}$ Corresponding author: kenneth.kalscheur@sdstate.edu
}

Key words: reduced-fat dried distillers grain with solubles, amino acid, lactating dairy cow, blood metabolite

\section{INTRODUCTION}

Ethanol production has increased remarkably in the last decade, resulting in large amounts of dried distillers grains with solubles (DDGS) as a valuable feedstuff for livestock animals. In fact, DDGS production by the corn dry grind industries increased from approximately 2.7 million metric tonnes in 2000 to approximately 23 million metric tonnes in 2008 and this growth is projected to continue in the near feature (RFA, 2009). New products are emerging because of this sustained growth. Reduced-fat DDGS (RFDG) is an example of this growth. The use of a solvent extraction process that removes corn oil from distillers grains results in a product that is lower in fat compared with conventional DDGS.

Dried distillers grains with solubles can be effectively added to dairy cow diets up to $20 \%$ of the ration DM without negatively affecting lactation performance (Anderson et al., 2006; Kleinschmit et al., 2006). In fact, inclusion of DDGS at $20 \%$ of the diet resulted in increased milk production and $4 \%$ FCM while maintaining milk components (Leonardi et al., 2005; Anderson et al., 2006; Kleinschmit et al., 2006). Moreover, Janicek et al. (2008) fed 30\% DDGS to lactating dairy cows and reported linear increases in DMI and milk production. Conversely, when DDGS was fed in excess of $30 \%$ of total DM, a decrease in DMI and milk yield was observed (Owen and Larson, 1991; Kalscheur, 2005). Lysine is the most limiting AA for milk production when corn feedstuffs predominate in the diet (Guinard and Rulquin, 1995). A small decrease in milk protein percentage was observed when DDGS replaced soybean meal up to $20 \%$ of the diet DM (Owen and Larson, 1991; Kleinschmit et al., 2006). Moreover, Nichols et al. (1998) concluded that Lys was the first-limiting AA for milk protein synthesis in diets containing DDGS and that supplementing ruminally protected Lys and Met to diets containing 20\% DDGS resulted in an increase in 
both milk production and milk protein. In contrast, Liu et al. (2000) found that feeding additional Lys did not improve either milk production or milk protein when cows were fed DDGS at $19 \%$ of the diet DM. When DDGS was fed at concentrations less than 20\% (Nichols et al., 1998; Liu et al., 2000; Kleinschmit et al., 2006), Lys was consistently cited as first-limiting amino acid, whereas milk protein percentage was only decreased in one report (Kleinschmit et al., 2006). However, there are no published data on amino acid utilization by the mammary gland from diets containing more than $20 \%$ of DDGS.

With the improved production processes of DDGS, heat damage is less likely to occur. In addition, removal of a portion of the fat in RFDG may reduce the potential for reduced milk fat percentage. Consequently, this may allow for a greater inclusion of this byproduct in dairy rations. We hypothesize that the inclusion of RFDG up to $30 \%$ of the diet would support milk and milk protein production in mid-lactation cows similar to a soybean protein-based diet. The objective of this study was to investigate the effects of feeding increasing amounts of RFDG at the expense of soybean products to mid-lactation dairy cows on milk production, milk composition, plasma metabolites, plasma amino acids, and amino acid utilization by the mammary gland as determined by the arteriovenous (AV) technique.

\section{MATERIALS AND METHODS}

\section{Animals and Diets}

Forty-one Holstein cows (22 multiparous averaging $745 \pm 45 \mathrm{~kg}$ of BW and $176 \pm 45$ DIM, and 19 primiparous averaging $674 \pm 55 \mathrm{~kg}$ of $\mathrm{BW}$ and $188 \pm 48$ DIM) were fed diets containing either soybean products or increasing concentrations of RFDG as the primary source of dietary protein (Table 1). Inclusion of RFDG proportionally replaced soybean products, and the inclusion rates of forages and corn were maintained almost constant across diets. Dietary treatments were 1) 0\% RFDG, 2) 10\% RFDG, 3) 20\% RFDG, and 4) $30 \%$ RFDG. Cows were stratified by DIM within parity and randomly assigned to 1 of the 4 treatments in a completely randomized design. The RFDG fed throughout the study was produced by a solvent-extraction process from a single batch supplied by VeraSun (Brookings, $\mathrm{SD})$. Diets were formulated to be isoenergetic (1.57 $\mathrm{Mcal} / \mathrm{kg}$ of $\left.\mathrm{NE}_{\mathrm{L}}\right)$, isonitrogenous $(18 \% \mathrm{CP})$, isolipidic (4.0\% ether extract), and isofibrous (37\% NDF), according to the NRC (2001). Cows were fed for ad libitum intake a common diet for a 2 -wk covariate period, followed by the experimental diets for $6 \mathrm{wk}$ (Table 1 ). The diet $\left(18 \% \mathrm{CP}, 1.79 \mathrm{Mcal}\right.$ of $\left.\mathrm{NE}_{\mathrm{L}} / \mathrm{d}\right)$ fed during the
Table 1. Ingredient composition (DM \% basis) of diets containing $0,10,20$, or $30 \%$ reduced-fat dried distillers grains with solubles (RFDG)

\begin{tabular}{lrrrr}
\hline & \multicolumn{4}{c}{ Dietary treatment, \% RFDG } \\
\cline { 2 - 5 } Ingredient & \multicolumn{1}{c}{0} & 10 & \multicolumn{1}{c}{20} & 30 \\
\hline Corn silage & 38.0 & 38.0 & 38.0 & 38.0 \\
Alfalfa hay & 12.0 & 12.0 & 12.0 & 12.0 \\
Ground corn & 17.6 & 17.3 & 16.8 & 16.3 \\
RFDG & 0.0 & 10.0 & 20.0 & 30.0 \\
Soybean meal, 44\% & 8.1 & 5.3 & 2.7 & 0.0 \\
Expeller soybean meal $^{1}$ & 9.3 & 6.2 & 3.1 & 0.0 \\
Soybean hulls $_{\text {Limestone }}$ & 12.0 & 8.0 & 4.0 & 0.0 \\
Rumen-inert fat $^{2}$ & 1.21 & 1.39 & 1.54 & 1.71 \\
Dicalcium phosphate $_{\text {Sodium bicarbonate }}$ & 0.44 & 0.62 & 0.84 & 0.98 \\
Magnesium oxide $_{\text {Salt }}$ & 0.29 & 0.18 & 0.09 & 0.00 \\
Vitamin premix $^{3}$ & 0.52 & 0.52 & 0.52 & 0.52 \\
l $^{2}$ & 0.20 & 0.20 & 0.20 & 0.20 \\
& 0.14 & 0.14 & 0.14 & 0.14 \\
& 0.16 & 0.16 & 0.16 & 0.16 \\
\hline
\end{tabular}

${ }^{1}$ SoyPlus (West Central Soy, Ralston, IA).

${ }^{2}$ Energy Booster 100 (Milk Specialties, Dundee, IL).

${ }^{3}$ Contained: $10 \% \mathrm{Mg} ; 2.6 \% \mathrm{Zn} ; 1.7 \mathrm{mg} / \mathrm{kg} \mathrm{Mn} ; 4,640 \mathrm{mg} / \mathrm{kg}$ Fe; 4,712 $\mathrm{mg} / \mathrm{kg} \mathrm{Cu} ; 396 \mathrm{mg} / \mathrm{kg} \mathrm{I} ; 119 \mathrm{mg} / \mathrm{kg}$ Co; $140 \mathrm{mg} / \mathrm{kg} \mathrm{Se} ; 2,640,000 \mathrm{IU} /$ $\mathrm{kg}$ vitamin $\mathrm{A} ; 528,000 \mathrm{IU} / \mathrm{kg}$ vitamin $\mathrm{D}_{3}$; and 10,560 IU $/ \mathrm{kg}$ vitamin $\mathrm{E}$ (Land O'Lakes, St. Paul, MN).

covariate period contained $44 \%$ forages (alfalfa, corn silage), $52.5 \%$ concentrates (steam-flaked corn, whole cottonseed, DDGS, soybean meal, expellers soybean meal, porcine meat and bone meal, rumen inert fat, and fish meal), and $3.5 \%$ vitamins and minerals. Cows were fed once daily at $0800 \mathrm{~h}$. As-fed diet composition was adjusted weekly to account for forage DM variation. All procedures for this study were conducted according to the South Dakota State University Animal Care and Use Committee guidelines.

\section{Sampling and Analysis}

Individual forages, concentrate mixes, and diets samples were collected weekly at the time of feeding, dried at $55^{\circ} \mathrm{C}$ for $48 \mathrm{~h}$, and composited by 3 -wk periods. Individual ingredients were sampled during the preparation of the concentrate mixes. All feed samples were ground to pass through a $2-\mathrm{mm}$ screen of a Wiley mill (model 3, Arthur H. Thomas Co., Philadelphia, $\mathrm{PA}$ ), and then reground through a $1-\mathrm{mm}$ screen of an ultracentrifuge mill (Brinkman Instruments Co., Westbury, NY) and analyzed for DM $\left(105^{\circ} \mathrm{C}\right.$ for $\left.24 \mathrm{~h}\right)$, NDF with sodium sulfite and $\alpha$-amylase (Van Soest et al., 1991), and ADF (Robertson and Van Soest, 1981) sequentially using an Ankom fiber analyzer (Ankom Technology Corp., Fairport, NY). Crude protein was determined by macro-Kjeldahl procedure (method 955.04; AOAC, 2002). Ether extract (EE) was determined using an Ankom ${ }^{\mathrm{XT10}}$ extractor with petroleum 
ether as the solvent (method 920.39; AOAC, 2002). Ash, $\mathrm{Ca}, \mathrm{P}, \mathrm{K}, \mathrm{Mg}$, and $\mathrm{S}$ were analyzed according to AOAC procedures (AOAC, 2002). Starch concentration of concentrate mixes, forages, and concentrate ingredients were analyzed using a starch assay kit (Megazyme International Ireland Ltd., Wicklow, Ireland; method 996.11; AOAC, 2002). Samples of corn silage, alfalfa, RFDG, and concentrate mixes were analyzed for AA composition according to AOAC (method 994.12, Alternative I; AOAC, 2002). Before AA determinations, samples of feeds were pre-oxidized with performic acid and hydrolyzed with $6 \mathrm{~N} \mathrm{HCl}$ to limit destruction of Met and Cys. Then, AA were resolved by isocratic ion exchange chromatography using acidic Na-citrate buffer as eluant. After elution from the column, the AA were derivatized using a PCX 5200 postcolumn derivatizer using ninhydrin (Pickering Laboratories Inc., Mountain View, CA) and quantified via HPLC (model 1100, Agilent Technologies Inc., Palo Alto, CA).

Chemical composition of diets was calculated based on analysis of individual forages and concentrate mixes and the dietary proportions of each ingredient in the ration. Samples of the TMR were also analyzed to validate the calculated chemical composition. Particle size distributions were evaluated for all diets as TMR using the Penn State Particle Separator (PSPS). The contents of each fraction were weighed and analyzed for DM and NDF as described earlier. Physical effectiveness factors (pef) for diets were calculated as the sum of the proportion of DM retained on 2 sieves, 19- and 8-mm ( pef $_{\text {ps-2s }}$; Lammers et al., 1996), or on 3 sieves, 19-, 8-, and 1.18-mm ( pef $_{\text {ps-3s }}$; Kononoff et al., 2003). Physically effective NDF (peNDF) was calculated as the proportion of DM retained by 2 sieves (19- and 8-mm screens; $\mathbf{p e N D F}_{\mathrm{ps-2s}}$ ) or by 3 sieves (19-, 8-, and 1.18-mm screens; $\mathbf{p e N D F}_{\mathrm{ps}-3 \mathrm{~s}}$ ), multiplied by dietary NDF concentration of the corresponding sieve.

Cows were milked 3 times daily at 0600, 1400, and $2100 \mathrm{~h}$, and yields were electronically recorded. Milk samples were collected for each milking on 3 consecutive days during the final week of the covariate period and $1 \mathrm{~d}$ per week during the 6-wk experimental period. Daily milk samples were pooled based upon yield at each milking and analyzed by Heart of America DHIA Laboratory (Manhattan, KS) according to approved procedures of AOAC (2002). Milk true protein, fat, and lactose were determined by near infrared spectroscopy (Bentley 2000 Infrared Milk Analyzer, Bentley Instruments, Chaska, MN). Concentration of MUN was determined using chemical methodology based on a modified Berthelot reaction (ChemSpec 150 Analyzer, Bentley Instruments), and somatic cells were counted using a flow cytometer laser (Somacount 500, Bentley
Instruments). Cows were weighed on 3 consecutive days and scored for body condition by 3 individuals at the start and the end of the study (Wildman et al., 1982), approximately $3 \mathrm{~h}$ postfeeding.

Blood samples were collected $3 \mathrm{~h}$ postfeeding during 3 consecutive days in the final week of the experiment and were composited to yield 1 pair of arterial and venous samples for each cow. Two sets of blood samples were collected by venipuncture from the coccygeal artery (arterial sample) and the caudal superficial epigastric vein (mammary venous sample) using K-EDTA and lithium-heparin containing vacutainer tubes (Becton Dickinson and Co., Franklin Lakes, NJ). Tubes with K-EDTA were used for glucose, BHBA, and total cholesterol analyses. Lithium-heparin containing tubes were used for AA, urea N (PUN), 3-methylhistidine, and ornithine determinations. Plasma was obtained by centrifuging at $2,400 \times g$ for $20 \mathrm{~min}$, and was then stored at $-20^{\circ} \mathrm{C}$. Arterial and venous samples for each cow were analyzed for AA, PUN, 3-methylhistidine, and ornithine via HPLC (model 1100, Agilent Technologies Inc.) with a PCX 5200 postcolumn derivatizer (Pickering Laboratories Inc.) using ninhydrin as described by Mondina et al. (1972), Pickering (1989), and Grunau and Swiader (1992). Arterial concentrations of glucose, BHBA, and total cholesterol were determined in triplicate using a microplate spectrophotometer (Varian Inc., Walnut Creek, CA). Commercial enzymatic kits (Pointe Scientific Inc., Canton, MI) were used to determine the following: plasma glucose using glucose oxidase (cat. no. G7521) according to Trinder (1969); BHBA using $\beta$-hydroxybutyrate dehydrogenase and diaphorase (cat. no. H7587-58) according to Williamson et al. (1962); and total cholesterol using cholesterol esterase and oxidase (cat. no. C7510) according to Allain et al. (1974).

\section{Calculations and Statistical Analyses}

Net energy intake ( $\mathbf{N E}_{\mathbf{I}}, \mathrm{Mcal} / \mathrm{d}$ ) was calculated by multiplying DMI by the estimated $\mathrm{NE}_{\mathrm{L}}$ density of the diet (NRC, 2001). Net energy required for maintenance $\left(\mathrm{NE}_{\mathrm{M}}, \mathrm{Mcal} / \mathrm{d}\right)$ was calculated as $\mathrm{BW}^{0.75} \times 0.08 \mathrm{NRC}$ (2001). Net energy required for lactation $\left(\mathrm{NE}_{\mathrm{L}}, \mathrm{Mcal} / \mathrm{d}\right)$ was calculated as milk yield $(\mathrm{kg} / \mathrm{d}) \times[(0.0929 \times \%$ fat $)$ $+(0.0563 \times \%$ protein $)+(0.0395 \times \%$ lactose $)](\mathrm{NRC}$, 2001). Energy balance (EB, Mcal/d) was estimated as $\mathrm{EB}=\mathrm{NE}_{\mathrm{I}}-\left(\mathrm{NE}_{\mathrm{M}}+\mathrm{NE}_{\mathrm{L}}\right)$.

Mammary plasma flow (MPF) was estimated according to the Fick principle, using Phe and Tyr as internal markers (Mepham, 1982), with allowance for a $3.5 \%$ contribution from bloodborne proteins according to Cant et al. (1993) and with the exception that the free milk Phe and Tyr values were neglected: 
Mammary plasma flow $=[($ milk Phe + Tyr $)$

$\times 0.965 /(\mathrm{AV}$ difference of $(\mathrm{Phe}+\mathrm{Tyr})]$.

Estimates of Phe and Tyr concentrations in milk of 4.9 and $5.1 \mathrm{~g} / 100 \mathrm{~g}$ of milk protein, respectively, were used (Jacobson et al., 1970). Extraction efficiency and mammary uptake of AA were calculated as follows:

$$
\begin{gathered}
\text { Extraction efficiency }=\text { AV difference } / \\
\text { arterial concentration } \times 100,
\end{gathered}
$$$$
\text { Mammary uptake }=\text { AV difference }
$$$$
\times \text { mammary plasma flow. }
$$

Amino acids were grouped according to their essentiality for milk protein synthesis in lactating cows (Clark et al., 1978). Essential amino acids (EAA) included Arg, His, Ile, Leu, Lys, Met, Phe, Thr, Trp, and Val; nonessential amino acids (NEAA) were Ala, Asn, Asp, Cys, Gln, Glu, Gly, Pro, Ser, and Tyr ; and branchedchain amino acids (BCAA) were Ile, Leu, and Val. Total amino acids (TAA) was calculated as the sum of EAA and NEAA.

Data collected during the 2-wk covariate period were used as covariables in data analysis. Weekly means of DMI, milk yield and composition (SCC data were log-transformed), and plasma measurements, BW, and BCS collected during wk 6 of the experimental period were used for statistical analysis. Analysis of variance was conducted using the MIXED procedure of SAS (SAS Institute, 2001). Pretreatment values for all measurements except blood measurements were used as covariables in the statistical model. Plasma measurements were analyzed using the same model except that week and corresponding interactions were not included in the model. The model was

$$
\begin{aligned}
& Y_{i j k l}=\mu+\operatorname{Cov}+T_{i}+P_{j}+C_{k}\left(T_{i} \times P_{j}\right)+W_{l}+T_{i} \\
& \times P_{j}+T_{i} \times W_{l}+P_{j} \times W_{l}+T_{i} \times P_{j} \times W_{l}+e_{i j k l},
\end{aligned}
$$

where $Y_{i j k l}=$ dependent variable, $\mu=$ overall mean, $C o v$ $=$ covariate; $T_{i}=$ effect of treatment $(i=1$ to 4$) ; P_{j}$ $=$ effect of parity $(j=1$ or 2$) ; C_{k}\left(T_{i} \times P_{j}\right)=$ random effect of cow nested within treatment and parity; $W_{l}=$ effect of week ( $l=1$ to 6$) ; T_{i} \times P_{j}=$ interaction between treatment and parity; $T_{i} \times W_{l}=$ interaction between treatment and week; $P_{j} \times W_{l}=$ interaction between parity and week; $T_{i} \times P_{j} \times W_{l}=$ interaction between treatment, parity, and week; and $e_{i j k l}=$ residual error. Week was used in the repeated measure statement with the selected covariance structure corresponding to the lowest value given by the Akaike's information criterion (Littell et al., 2006). Nonsignificant interactions were sequentially dropped from the model. Significant interactions are identified in the results. Orthogonal contrasts were used to test the linear, quadratic, and cubic effects of RFDG inclusion. Data were reported as least squares means. Statistical significance of main effects was declared at $P \leq 0.05$, and tendencies were accepted at $0.05<P \leq 0.10$.

\section{RESULTS}

\section{Diet Evaluation}

The chemical composition of individual ingredients is presented in Table 2. Chemical composition of dietary treatments is presented in Table 3. All diets contained similar concentrations of DM, CP, starch, and ash. Slight differences were observed in NDF and ADF, ranging from 40.7 to $42.0 \%$ and 18.8 to $20.9 \%$ for NDF and ADF, respectively. Although diets were formulated to be equal in EE, EE increased as RFDG increased in the diet (3.3 to $4.3 \%$ ).

Amino acid composition of concentrate mixes, forages, and RFDG are presented in Table 4 . The inclusion of RFDG in diets (Table 5) decreased concentrations of Arg, Asp, Gly, Ile, and Lys. In contrast, concentrations of Ala, Leu, Pro, and Met increased (Table 5). A slight decrease in total EAA was observed as RFDG replaced soybean feedstuffs in the diet. Total EAA was 38.23 and $36.55 \%$ of $\mathrm{CP}$, respectively, for diets with 0 and $30 \%$ RFDG. Lysine as a percentage of TEAA decreased by $27 \%$ when all soybean protein was replaced by RFDG, whereas Met as a percentage of TEAA increased by $31 \%$.

The particle size distribution of dietary treatments is presented in Table 6. As expected, the proportion of particles retained on the 8- and 19-mm sieves was similar for all diets; however, the proportion of material retained by the $1.18-\mathrm{mm}$ sieve decreased with increasing RFDG inclusion in the diets. As a result, pef $_{\mathrm{ps}-2 \mathrm{~s}}$ and peNDF ${ }_{\mathrm{ps}-2 \mathrm{~s}}$ were similar across diets and were less sensitive to dietary treatments because all treatments included similar proportions of forages. However, as RFDG replaced soybean products, fewer particles were retained by the $1.18-\mathrm{mm}$ sieve, and therefore pef $_{\mathrm{ps}-3 \mathrm{~s}}$ and $\mathrm{peNDF}_{\mathrm{ps}-3 \mathrm{~s}}$ decreased. Overall, those proportions, based on either 2 or 3 sieves, followed the recommendations for particle size for diet as TMR (Heinrichs and Kononoff, 2002).

\section{Intakes, Milk Yield, and Composition}

Dry matter intake, milk yield, and milk composition are presented in Table 7. Replacement of soybean prod- 
Table 2. Chemical composition (DM basis) of concentrate mixes, corn silage, alfalfa hay, and reduced-fat dried distillers grains with solubles (RFDG)

\begin{tabular}{|c|c|c|c|c|c|c|c|}
\hline \multirow[b]{2}{*}{ Item } & \multicolumn{4}{|c|}{ Concentrate mixture, \% RFDG } & \multirow[b]{2}{*}{ Corn silage } & \multirow[b]{2}{*}{ Alfalfa hay } & \multirow[b]{2}{*}{ RFDG } \\
\hline & 0 & 10 & 20 & 30 & & & \\
\hline DM, \% & 89.3 & 89.1 & 89.0 & 88.4 & 23.9 & 88.1 & 86.0 \\
\hline $\mathrm{CP}, \%$ of $\mathrm{DM}$ & 23.9 & 24.0 & 23.9 & 23.7 & 8.1 & 22.0 & 34.5 \\
\hline NDF, $\%$ of DM & 27.5 & 30.2 & 28.7 & 29.9 & 59.4 & 36.4 & 45.0 \\
\hline $\mathrm{ADF}, \%$ of $\mathrm{DM}$ & 12.6 & 11.9 & 9.7 & 8.4 & 31.1 & 23.3 & 12.9 \\
\hline Ether extract, $\%$ of DM & 3.3 & 3.1 & 4.5 & 5.1 & 3.8 & 2.3 & 3.5 \\
\hline Starch, $\%$ of DM & 26.9 & 26.9 & 26.5 & 27.4 & 10.6 & 1.8 & 4.2 \\
\hline Ash, $\%$ of DM & 9.6 & 9.6 & 9.6 & 9.4 & 5.5 & 12.3 & 5.2 \\
\hline $\mathrm{Ca}, \%$ of DM & 1.78 & 1.74 & 2.20 & 1.84 & 0.35 & 1.85 & 0.16 \\
\hline $\mathrm{P}, \%$ of $\mathrm{DM}$ & 0.49 & 0.49 & 0.56 & 0.53 & 0.23 & 0.32 & 0.85 \\
\hline $\mathrm{Mg}, \%$ of $\mathrm{DM}$ & 0.46 & 0.57 & 0.54 & 0.59 & 0.26 & 0.42 & 0.37 \\
\hline $\mathrm{K}, \%$ of $\mathrm{DM}$ & 1.22 & 1.04 & 0.89 & 0.69 & 1.11 & 2.04 & 1.02 \\
\hline S, \% of DM & 0.22 & 0.27 & 0.44 & 0.47 & 0.11 & 0.23 & 0.82 \\
\hline
\end{tabular}

ucts by RFDG as the primary source of protein did not affect DMI $(23.1 \mathrm{~kg} / \mathrm{d})$ or CP intake $(4.20 \mathrm{~kg} / \mathrm{d})$. Milk yield was similar and averaged $35.0 \mathrm{~kg} / \mathrm{d}$ during the entire experimental period. Yield of FCM increased linearly $(P=0.04)$ when inclusion of RFDG increased. Yield of ECM and efficiency of milk production, expressed as the ratio of ECM to DMI, tended to increase linearly $(P=0.06)$. Nitrogen efficiency expressed as milk $\mathrm{N}$ output $(\mathrm{kg} / \mathrm{d})$ per $\mathrm{N}$ intake $(\mathrm{kg} / \mathrm{d})$ was not affected by feeding higher concentrations of RFDG.
Milk fat percentage increased linearly $(P=0.05)$. In fact, inclusion of RFDG at $30 \%$ of diet DM increased fat yield by $240 \mathrm{~g} / \mathrm{d}$ compared with the control diet. Similarly, fat yield increased linearly $(P=0.04)$. There was a quadratic response $(P=0.02)$ in milk protein percentage such that cows fed the intermediate concentrations of RFDG had the highest milk protein percentage. Cows fed the $30 \%$ RFDG diet had the lowest protein percentage, but this result was similar to that of cows fed the control diet. There were no

Table 3. Chemical composition of diets (DM basis) containing 0, 10, 20, or 30\% reduced-fat dried distillers grains with solubles (RFDG) ${ }^{1}$

\begin{tabular}{|c|c|c|c|c|}
\hline \multirow[b]{2}{*}{ Item } & \multicolumn{4}{|c|}{ Dietary treatment, \% RFDG } \\
\hline & 0 & 10 & 20 & 30 \\
\hline DM, $\%$ & 46.0 & 46.0 & 45.5 & 45.5 \\
\hline $\mathrm{CP}, \%$ of $\mathrm{DM}$ & 17.7 & 17.7 & 17.6 & 17.6 \\
\hline $\mathrm{RUP}^{2} \% \mathrm{CP}$ & 10.1 & 10.1 & 10.1 & 10.0 \\
\hline RUP, ${ }^{2} \%$ CP & 7.6 & 7.6 & 7.6 & 7.6 \\
\hline Duodenal supply of Lys, ${ }^{2} \%$ of MP & 6.38 & 6.04 & 5.65 & 5.33 \\
\hline Duodenal supply Met, ${ }^{2} \%$ of MP & 1.72 & 1.73 & 1.73 & 1.75 \\
\hline Lys:Met as MP ${ }^{2}$ & 3.7 & 3.5 & 3.3 & 3.0 \\
\hline MP balance, ${ }^{2} \mathrm{~g} / \mathrm{d}$ & 427 & 356 & 400 & 229 \\
\hline $\mathrm{NDF}, \%$ of $\mathrm{DM}$ & 40.7 & 42.0 & 41.3 & 41.9 \\
\hline $\mathrm{ADF}, \%$ of $\mathrm{DM}$ & 20.9 & 20.6 & 19.5 & 18.8 \\
\hline NDF from forage, $\%$ of DM & 26.9 & 26.9 & 26.9 & 26.9 \\
\hline $\mathrm{NFC}^{3} \%$ of $\mathrm{DM}$ & 29.8 & 28.6 & 28.6 & 27.9 \\
\hline Ether extract, $\%$ of DM & 3.4 & 3.3 & 4.0 & 4.3 \\
\hline Starch, \% of DM & 17.7 & 17.7 & 17.5 & 17.9 \\
\hline Ash, \% of DM & 8.4 & 8.4 & 8.4 & 8.3 \\
\hline $\mathrm{Ca}, \%$ of $\mathrm{DM}$ & 1.24 & 1.22 & 1.45 & 1.27 \\
\hline $\mathrm{P}, \%$ of $\mathrm{DM}$ & 0.37 & 0.37 & 0.40 & 0.39 \\
\hline $\mathrm{K}, \%$ of $\mathrm{DM}$ & 1.28 & 1.19 & 1.11 & 1.01 \\
\hline $\mathrm{Mg}, \%$ of $\mathrm{DM}$ & 0.38 & 0.43 & 0.42 & 0.44 \\
\hline $\mathrm{S}, \%$ of DM & 0.18 & 0.20 & 0.29 & 0.30 \\
\hline $\mathrm{NE}_{\mathrm{L}},{ }^{2} \mathrm{Mcal} / \mathrm{kg}$ & 1.61 & 1.61 & 1.59 & 1.60 \\
\hline $\mathrm{NE}_{\mathrm{L}}$ balance, Mcal & 2.7 & 1.8 & 3.1 & -0.6 \\
\hline
\end{tabular}

${ }^{1}$ Calculated at 50:38:12 of concentrate mix, corn silage, and alfalfa hay, respectively.

${ }^{2}$ Estimated from NRC (2001) using actual feed analysis and average lactation performance for each treatment.

${ }^{3} \mathrm{NFC}=100-(\% \mathrm{NDF}+\% \mathrm{CP}+\%$ ether extract $+\%$ ash $)$. 
Table 4. Amino acid composition of concentrate mixes, corn silage, alfalfa hay, and reduced-fat dried distillers grains with solubles (RFDG)

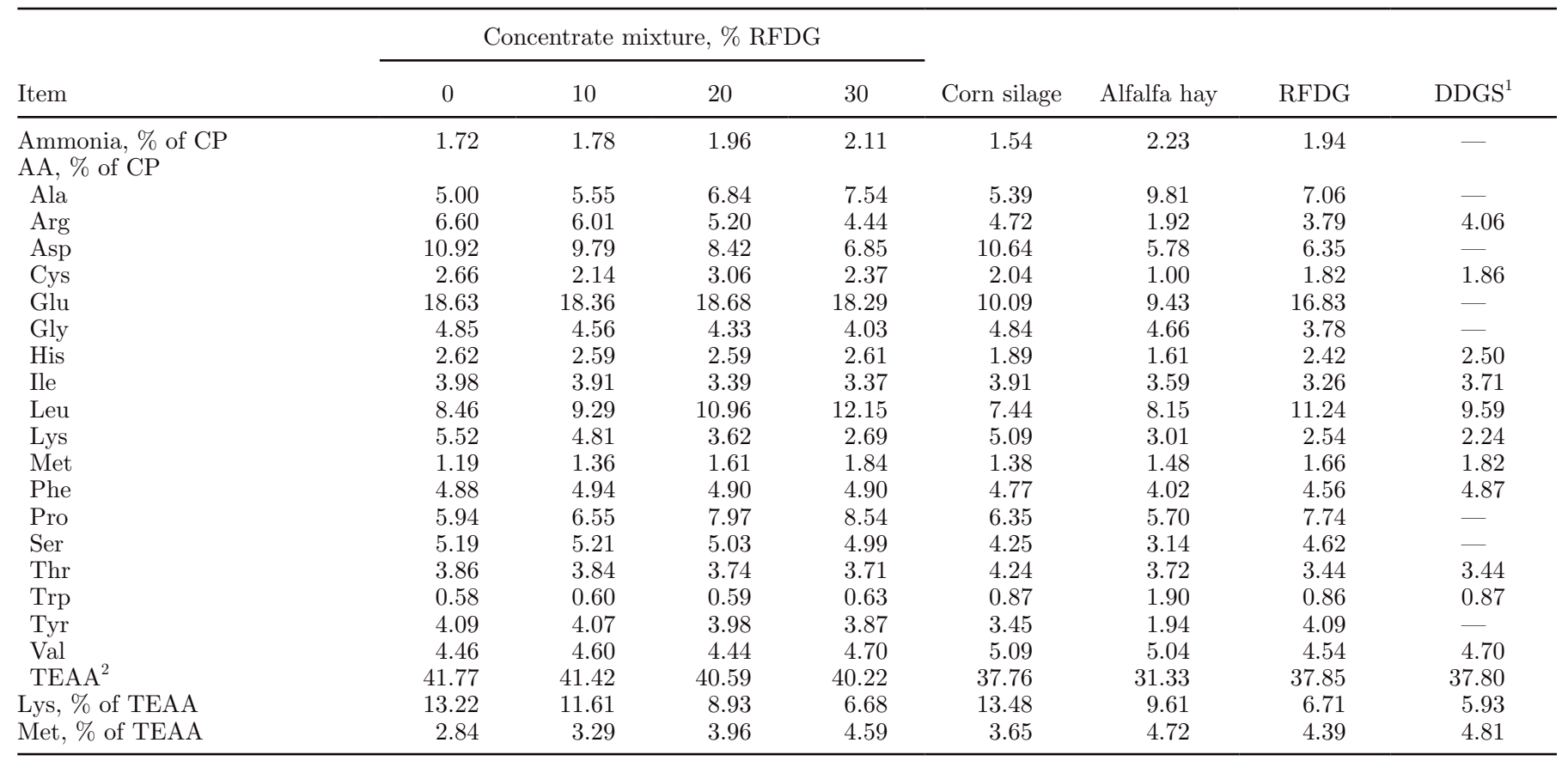

${ }^{1}$ Adapted from NRC (2001). DDGS = dried distillers grains witih solubles.

${ }^{2}$ TEAA $=$ total essential AA (Arg, His, Ile, Leu, Lys, Met, Phe, Thr, Trp, and Val).

Table 5. Amino acid composition of experimental diets containing 0, 10, 20, or 30\% reduced-fat dried distillers grains with solubles (RFDG) ${ }^{1}$

\begin{tabular}{|c|c|c|c|c|}
\hline \multirow[b]{2}{*}{ Item } & \multicolumn{4}{|c|}{ Dietary treatment, \% RFDG } \\
\hline & 0 & 10 & 20 & 30 \\
\hline Ammonia, $\%$ of $\mathrm{CP}$ & 1.89 & 1.92 & 2.01 & 2.09 \\
\hline \multicolumn{5}{|l|}{$\mathrm{AA}, \%$ of $\mathrm{CP}$} \\
\hline Ala & 6.87 & 7.15 & 7.80 & 8.14 \\
\hline Arg & 4.60 & 4.30 & 3.90 & 3.52 \\
\hline Asp & 8.93 & 8.37 & 7.68 & 6.90 \\
\hline Cys & 1.96 & 1.69 & 2.15 & 1.81 \\
\hline Glu & 14.11 & 13.97 & 14.13 & 13.94 \\
\hline Gly & 4.78 & 4.63 & 4.52 & 4.36 \\
\hline His & 2.15 & 2.13 & 2.13 & 2.14 \\
\hline Ile & 3.82 & 3.79 & 3.53 & 3.52 \\
\hline Leu & 8.22 & 8.63 & 9.47 & 10.06 \\
\hline Lys & 4.52 & 4.16 & 3.57 & 3.10 \\
\hline Met & 1.32 & 1.41 & 1.53 & 1.65 \\
\hline Phe & 4.54 & 4.57 & 4.55 & 4.55 \\
\hline Pro & 5.89 & 6.20 & 6.91 & 7.19 \\
\hline Ser & 4.30 & 4.31 & 4.22 & 4.20 \\
\hline Thr & 3.85 & 3.84 & 3.79 & 3.78 \\
\hline $\operatorname{Trp}$ & 1.12 & 1.13 & 1.12 & 1.14 \\
\hline Tyr & 3.20 & 3.19 & 3.14 & 3.09 \\
\hline Val & 4.76 & 4.83 & 4.75 & 4.88 \\
\hline $\mathrm{TEAA}^{2}$ & 38.23 & 37.15 & 36.73 & 36.55 \\
\hline Lys, $\%$ of TEAA & 11.81 & 11.08 & 9.73 & 8.61 \\
\hline Met, $\%$ of TEAA & 3.45 & 3.88 & 4.21 & 4.52 \\
\hline
\end{tabular}

${ }^{1}$ Calculated at 50:38:12 of concentrate mix, corn silage, and alfalfa hay, respectively.

${ }^{2}$ TEAA $=$ total essential AA (Arg, His, Ile, Leu, Lys, Met, Phe, Thr, Trp, and Val). 
MJOUN ET AL.

Table 6. Particle distribution using PSPS $^{1}$ and effective fiber of diet containing reduced-fat dried distillers grains with solubles (RFDG)

\begin{tabular}{|c|c|c|c|c|c|c|c|c|}
\hline Item $^{2}$ & \multicolumn{4}{|c|}{ Dietary treatment, \% RFDG } & SEM & \multicolumn{3}{|c|}{ Contrast $(P \text {-value })^{3}$} \\
\hline \multicolumn{9}{|c|}{ (\% retained, as-fed basis) } \\
\hline$>19 \mathrm{~mm}$ & 10.1 & 9.6 & 9.5 & 9.1 & 0.71 & 0.34 & 0.98 & 0.87 \\
\hline $8-19 \mathrm{~mm}$ & 37.7 & 37.9 & 38.9 & 38.3 & 0.98 & 0.52 & 0.71 & 0.85 \\
\hline $1.18-8 \mathrm{~mm}$ & 39.4 & 36.7 & 33.4 & 30.1 & 0.61 & $<0.01$ & 0.65 & 0.86 \\
\hline Bottom pan & 12.8 & 15.8 & 18.2 & 22.4 & 0.84 & $<0.01$ & 0.45 & 0.53 \\
\hline$>19 \mathrm{~mm}$ & 7.2 & 6.7 & 6.3 & 7.0 & 0.55 & 0.72 & 0.27 & 0.73 \\
\hline $8-19 \mathrm{~mm}$ & 37.7 & 35.6 & 40.4 & 37.3 & 1.00 & 0.43 & 0.63 & 0.01 \\
\hline $1.18-8 \mathrm{~mm}$ & 41.9 & 41.1 & 34.0 & 30.3 & 0.79 & $<0.01$ & 0.07 & $<0.01$ \\
\hline Bottom pan & 13.1 & 16.5 & 19.2 & 25.3 & 0.83 & $<0.01$ & 0.12 & 0.28 \\
\hline pef $_{\mathrm{ps}-2 \mathrm{~s}}$ & 47.8 & 47.5 & 48.4 & 47.4 & 0.85 & 0.96 & 0.67 & 0.46 \\
\hline pef $_{p s-3 s}$ & 87.2 & 84.2 & 81.8 & 77.6 & 0.84 & $<0.01$ & 0.45 & 0.53 \\
\hline peNDF $_{\mathrm{ps}-2 \mathrm{~s}}, \%$ of DM & 23.7 & 21.8 & 23.6 & 22.5 & 0.50 & 0.43 & 0.36 & $<0.01$ \\
\hline
\end{tabular}

${ }^{1}$ Penn State Particle Separator.

${ }^{2}$ pef $=$ physical effectiveness factor; pef $_{\mathrm{ps}-2 \mathrm{~s}}=$ proportion of particles retained by 2 sieves $(19$ and $8 \mathrm{~mm})$; pef ps-3s $=$ proportion of particles retained by 3 sieves $(19,8$, and $1.18 \mathrm{~mm})$; peNDF $=$ physically effective $\mathrm{NDF}$; peNDF $\mathrm{ps}_{2 \mathrm{~s}}=$ retained $\mathrm{NDF}$ concentration $\times$ amount of $\mathrm{DM}>8 \mathrm{~mm}$; $\mathrm{peNDF}_{\mathrm{ps}-3 \mathrm{~s}}=$ retained $\mathrm{NDF}$ concentration $\times$ amount of DM $>1.18 \mathrm{~mm}$.

${ }^{3}$ Contrasts: $\mathrm{L}=$ linear, $\mathrm{Q}=$ quadratic, and $\mathrm{C}=$ cubic.

differences in protein yield among diets and averaged $1.06 \mathrm{~kg} / \mathrm{d}$. Lactose concentration increased linearly $(P$ $=0.04)$, while lactose yield was not affected by increasing concentrations of RFDG in the diet. When cows consumed increased amounts of RFDG, there was a linear increase $(P=0.03)$ for total solids percentage in milk and a tendency for a linear increase in total solid yield $(P=0.06)$. Although dietary $\mathrm{CP}$ was similar for all diets, MUN decreased linearly $(P<0.01)$.

Significant interaction effects of parity $\times$ week were observed for milk and lactose yields $(P<0.05)$. During the first 2 wk of the experiment, multiparous cows produced greater yields, whereas primiparous cows had greater yields during the last $4 \mathrm{wk}$ of the experiment resulting in an interaction. Significant interaction effects of treatment $\times$ week were observed for milk fat and total solids percentages $(P<0.05)$.

\section{BW, Energy Balance, and Plasma Metabolites}

Body weight and BW change were not affected by treatment (Table 8). Body condition scores and BCS change responded quadratically with lower values for cows fed the 10 and 20\% RFDG diets. Net energy intake tended to respond in a quadratic manner to increased concentrations of RFDG in the diet; cows fed the $20 \%$ RFDG diets consumed the greatest amount of net energy (Table 8). There was a linear increase for estimated net energy required for lactation $(P=$ 0.04 ) because of a linear increase in the output of milk constituents. Net energy required for maintenance was similar for all diets. Net energy balance was slightly positive for all treatments except for cows fed the $30 \%$ RFDG diet, where estimated energy balance was -0.81 $\mathrm{Mcal} / \mathrm{d}$. Energy efficiency for lactation, expressed as $\mathrm{NE}_{\mathrm{L}}$ divided by $\mathrm{NE}_{\mathrm{I}}$, increased linearly $(P=0.05)$.

Plasma metabolites are presented in Table 9. Proportional replacement of soybean products by RFDG resulted in a linear increase $(P=0.01)$ in the concentration of plasma glucose and total cholesterol, and a linear decrease $(P<0.01)$ in PUN and ornithine. There was no effect of treatment on plasma concentrations of BHBA, 3-methylhistidine, or ammonia.

\section{Plasma Amino Acids}

Estimated mammary plasma flow rates in terms of liters per day and liters per kilogram of milk (Table 9) were not significantly affected by treatment, although MPF rates increased numerically when RFDG increased in the diet. The mean ratio of MPF to milk yield was $531 \pm 44: 1$ ( vol/vol) for all diets.

Arterial concentrations of individual AA, EAA, NEAA, BCAA, and TAA are presented in Table 10. The arterial concentration of all EAA reflected the dietary profile of AA. Arterial His, Leu, Met, Gly, Pro, Ser, and Tyr increased linearly $(P<0.01)$ as RFDG replaced soybean products in the diet, whereas concentrations of Lys, Arg, and Ile decreased linearly. Arterial Met increased almost 2-fold by substituting all soybean protein sources with RFDG, whereas Lys decreased by $33 \%$. The ratio of plasma Met to Lys paralleled that in 
Table 7. Dry matter intake, milk yield, and milk composition by dairy cows fed $0,10,20$, or $30 \%$ reduced-fat dried distillers grains with solubles (RFDG)

\begin{tabular}{|c|c|c|c|c|c|c|c|c|}
\hline \multirow[b]{2}{*}{ Item } & \multicolumn{4}{|c|}{ Dietary treatment, \% RFDG } & \multirow[b]{2}{*}{ SEM } & \multicolumn{3}{|c|}{ Contrast $(P \text {-value })^{1}$} \\
\hline & 0 & 10 & 20 & 30 & & $\mathrm{~L}$ & $\mathrm{Q}$ & $\mathrm{C}$ \\
\hline \multicolumn{9}{|l|}{ Intake } \\
\hline DM, $\mathrm{kg} / \mathrm{d}$ & 22.7 & 23.0 & 23.7 & 22.2 & 0.78 & 0.74 & 0.20 & 0.37 \\
\hline $\mathrm{CP}, \mathrm{kg} / \mathrm{d}$ & 4.0 & 4.1 & 4.2 & 4.0 & 0.14 & 0.88 & 0.29 & 0.48 \\
\hline \multicolumn{9}{|l|}{ Production } \\
\hline Milk, kg/d & 34.5 & 34.8 & 35.5 & 35.2 & 0.62 & 0.34 & 0.62 & 0.59 \\
\hline $\mathrm{ECM},{ }^{2} \mathrm{~kg} / \mathrm{d}$ & 32.6 & 34.6 & 35.6 & 36.0 & 1.33 & 0.06 & 0.51 & 0.93 \\
\hline $\mathrm{FCM}^{3}{ }^{3} \mathrm{~kg} / \mathrm{d}$ & 30.0 & 31.7 & 32.1 & 33.1 & 1.04 & 0.04 & 0.75 & 0.63 \\
\hline \multicolumn{9}{|l|}{ Efficiency } \\
\hline Feed efficiency ${ }^{4}$ & 1.47 & 1.53 & 1.49 & 1.61 & 0.05 & 0.06 & 0.50 & 0.22 \\
\hline $\mathrm{N}$ efficiency ${ }^{5}$ & 25.5 & 27.0 & 25.8 & 26.0 & 0.78 & 0.88 & 0.39 & 0.23 \\
\hline \multicolumn{9}{|l|}{ Milk composition } \\
\hline Fat, $\%$ & 3.18 & 3.40 & 3.46 & 3.72 & 0.18 & 0.05 & 0.89 & 0.64 \\
\hline Fat yield, $\mathrm{kg} / \mathrm{d}$ & 1.08 & 1.19 & 1.23 & 1.32 & 0.08 & 0.04 & 0.86 & 0.72 \\
\hline Protein, $\%$ & 2.99 & 3.06 & 3.13 & 2.99 & 0.04 & 0.77 & 0.02 & 0.33 \\
\hline Protein yield, $\mathrm{kg} / \mathrm{d}$ & 1.03 & 1.07 & 1.10 & 1.06 & 0.02 & 0.25 & 0.15 & 0.60 \\
\hline Lactose, \% & 4.95 & 4.96 & 4.94 & 5.06 & 0.03 & 0.04 & 0.13 & 0.21 \\
\hline Lactose yield, $\mathrm{kg} / \mathrm{d}$ & 1.71 & 1.74 & 1.75 & 1.76 & 0.03 & 0.33 & 0.79 & 0.83 \\
\hline Total solids, $\%$ & 12.10 & 12.39 & 12.40 & 12.67 & 0.17 & 0.03 & 0.91 & 0.42 \\
\hline Total solids, kg/d & 4.15 & 4.35 & 4.43 & 4.45 & 0.11 & 0.06 & 0.44 & 0.87 \\
\hline MUN, mg/dL & 15.84 & 14.62 & 13.68 & 13.03 & 0.42 & $<0.01$ & 0.46 & 0.99 \\
\hline $\mathrm{SCS}^{6}$ & 4.42 & 4.08 & 4.44 & 4.31 & 0.33 & 0.33 & 0.22 & 0.34 \\
\hline
\end{tabular}

${ }^{1}$ Contrasts: $\mathrm{L}=$ linear, $\mathrm{Q}=$ quadratic, and $\mathrm{C}=$ cubic.

${ }^{2} \mathrm{ECM}=[0.327 \times$ milk yield $(\mathrm{kg})]+[12.95 \times$ fat yield $(\mathrm{kg})]+[7.2 \times$ protein yield $(\mathrm{kg})]$.

${ }^{3} \mathrm{FCM}=[0.4 \times$ milk yield $(\mathrm{kg})]+[15 \times$ fat yield $(\mathrm{kg})]$.

${ }^{4}$ Feed efficiency $=(\mathrm{ECM} / \mathrm{DMI})$.

${ }^{5}$ Nitrogen efficiency $=$ milk $\mathrm{N}(\mathrm{kg} / \mathrm{d}) / \mathrm{N}$ intake $(\mathrm{kg} / \mathrm{d})$.

${ }^{6} \mathrm{SCS}=\log (\mathrm{SCC})$.

the diets $(\mathrm{r}=0.99)$, varying from 4.00 to 1.52 for 0 and $30 \%$ RFDG, respectively. Nonessential amino acids and TAA increased linearly $(P<0.05)$. The AV differences (Table 11) of Ala, Lys, and Ser were decreased by the addition of RFDG. The extraction efficiency of His, Leu, Met, Trp, and Tyr decreased linearly $(P<0.01$; Table 12). Similarly, extraction efficiency of Phe, Ala, and Gln tended to decrease linearly. The extraction efficiency of Lys and Arg increased linearly $(P<0.01)$. Nonessential AA and TAA extraction efficiencies also tended to decrease in RFDG diets.

Mammary uptake of AA per kilogram of milk was not affected by treatment, except for a linear increase in Leu uptake and a tendency for an increase in Glu

Table 8. Body weight, BCS, and energy balance of dairy cows fed 0, 10, 20, or 30\% reduced-fat dried distillers grains with solubles (RFDG)

\begin{tabular}{|c|c|c|c|c|c|c|c|c|}
\hline \multirow[b]{2}{*}{ Item } & \multicolumn{4}{|c|}{ Dietary treatment, \% RFDG } & \multirow[b]{2}{*}{ SEM } & \multicolumn{3}{|c|}{ Contrast $(P \text {-value })^{1}$} \\
\hline & 0 & 10 & 20 & 30 & & $\mathrm{~L}$ & $\mathrm{Q}$ & $\mathrm{C}$ \\
\hline $\mathrm{BW}, \mathrm{kg}$ & 705 & 713 & 721 & 710 & 6.8 & 0.41 & 0.15 & 0.50 \\
\hline BW change, g/d & -167 & 15 & 230 & -36 & 161 & 0.39 & 0.15 & 0.44 \\
\hline $\mathrm{BCS}^{2}$ & 3.56 & 3.37 & 3.36 & 3.53 & 0.07 & 0.66 & 0.02 & 0.99 \\
\hline BCS change & 0.15 & -0.05 & -0.07 & 0.15 & 0.09 & 0.99 & 0.02 & 0.86 \\
\hline $\mathrm{NE}_{\mathrm{I}},{ }^{3} \mathrm{Mcal} / \mathrm{d}$ & 34.7 & 37.0 & 38.3 & 35.2 & 1.55 & 0.69 & 0.09 & 0.61 \\
\hline $\mathrm{NE}_{\mathrm{M},}{ }^{4} \mathrm{Mcal} / \mathrm{d}$ & 10.9 & 11.2 & 11.0 & 11.0 & 0.20 & 0.94 & 0.52 & 0.30 \\
\hline $\mathrm{NE}_{\mathrm{L}},{ }^{5} \mathrm{Mcal} / \mathrm{d}$ & 22.6 & 24.0 & 24.7 & 25.0 & 0.80 & 0.04 & 0.52 & 0.90 \\
\hline $\mathrm{EB},{ }^{6} \mathrm{Mcal} / \mathrm{d}$ & 3.18 & 1.60 & 2.80 & -0.81 & 1.20 & 0.07 & 0.32 & 0.09 \\
\hline Energy efficiency ${ }^{7}$ & 64.6 & 66.8 & 64.2 & 71.2 & 0.70 & 0.05 & 0.22 & 0.10 \\
\hline
\end{tabular}

${ }^{1}$ Contrasts: $\mathrm{L}=$ linear, $\mathrm{Q}=$ quadratic, and $\mathrm{C}=$ cubic.

${ }^{2}$ Body condition score: $1=$ emaciated to $5=$ obese (Wildman et al., 1982).

${ }^{3}$ Net energy intake $=\mathrm{NE}_{\mathrm{L}}(\mathrm{Mcal} / \mathrm{kg}) \times \mathrm{DMI}(\mathrm{kg} / \mathrm{d})$.

${ }^{4}$ Net energy for maintenance $=\mathrm{BW}^{0.75} \times 0.08(\mathrm{NRC}, 2001)$.

${ }^{5}$ Net energy required for milk $=$ milk yield $(\mathrm{kg}) \times[(0.0929 \times$ fat $\%)+(0.0563 \times$ protein $\%)+(0.0395 \times$ lactose $\%)](\mathrm{NRC}, 2001)$.

${ }^{6}$ Energy balance $=\mathrm{NE}_{\mathrm{I}}-\left(\mathrm{NE}_{\mathrm{M}}+\mathrm{NE}_{\mathrm{L}}\right)$.

${ }^{7}$ Energy efficiency $=\mathrm{NE}_{\mathrm{L}} / \mathrm{NE}_{\mathrm{I}}$. 
Table 9. Calculated mammary plasma flow and plasma metabolites (mmol/L unless otherwise noted) in dairy cows fed reduced-fat dried distillers grains with solubles (RFDG)

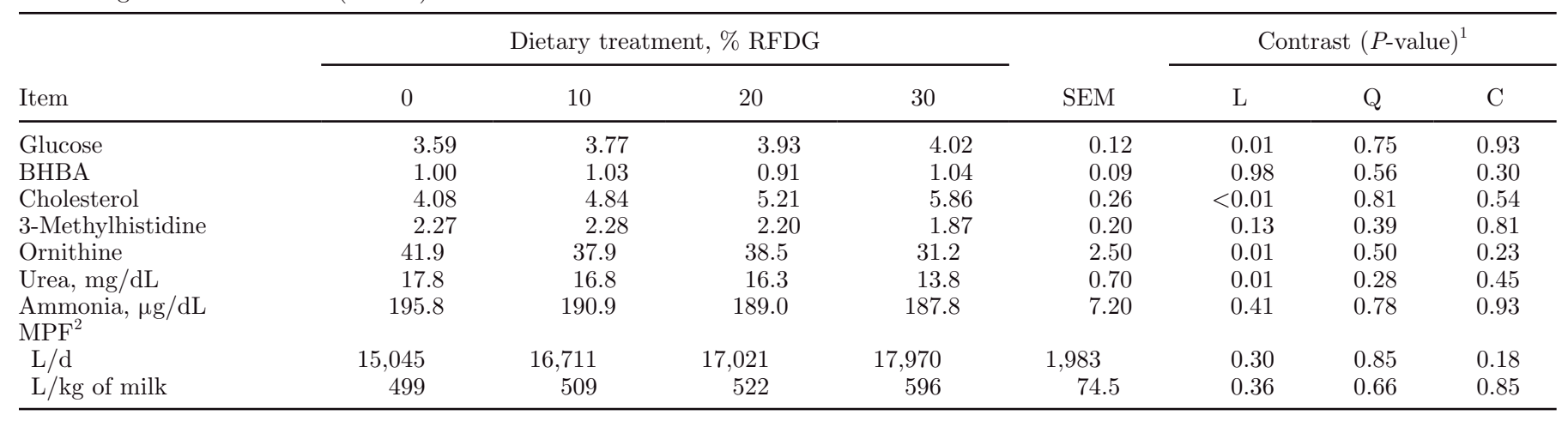

${ }^{1}$ Contrasts: $\mathrm{L}=$ linear, $\mathrm{Q}=$ quadratic, and $\mathrm{C}=$ cubic.

${ }^{2}$ Mammary plasma flow $=[($ milk Phe + Tyr $) \times 0.965 /($ arterial-venous difference of $($ Phe + Tyr $)]($ Cant et al., 1993).

uptake in RFDG diets (Table 13). Uptake to output ratio (data not presented) was greater than 1.0 for most EAA. Of the EAA, only Leu showed a significant linear increase in the uptake to output ratio $(P<0.01)$.

\section{DISCUSSION}

\section{Diet Evaluation}

The nutrient composition of alfalfa was comparable to that reported in the NRC (2001). Corn silage used in this study was lower in starch $(10.6 \%)$ and higher in NDF (59.4\%) compared with typical corn silage. The AA profiles of alfalfa and corn silage were similar to those published in the NRC (2001). The CP and NDF concentrations of RFDG were greater than usually reported for regular DDGS (NRC, 2001; Spiehs et al., 2002), whereas ADF and EE concentrations were less than the NRC (2001) values. The low EE concentration in RFDG was a result of a solvent-extraction process that removes corn oil from DDGS.

When the AA composition of RFDG was compared with DDGS listed in the NRC (2001), slight variations existed. The RFDG contained lower concentration of Arg, Ile, and Met, and higher concentration of Leu and Lys. Total EAA as a percentage of $\mathrm{CP}$ was similar for RFDG compared with the value reported in NRC (2001) for DDGS.

Diets were similar to original formulations, except that NDF and ADF concentrations ranged from 40.7 to $42.0 \%$ and 18.8 to $20.9 \%$, respectively (Table 3 ). Original formulations assumed 37.0 and $20.0 \%$ for NDF and ADF, respectively. This difference resulted from the higher NDF concentration in RFDG and corn silage used during this study. The low starch concentration in corn silage resulted in relatively low dietary concentration of starch (17.7\%). Crude protein contribution from
RFDG increased from 0 to $58 \%$ of the total dietary supply of CP as RFDG replaced soybean products.

Metabolizable protein and $\mathrm{NE}_{\mathrm{L}}$ were evaluated by the NRC (2001) system using lactation performance results and actual nutrient composition for each experimental diet. Diets supplied on average $114.6 \%(\mathrm{SD}=3.5)$ and $105.0 \%(\mathrm{SD}=4.9)$ of daily requirements for $\mathrm{MP}$ and $\mathrm{NE}_{\mathrm{L}}$, respectively.

To maximize milk and milk protein production, the NRC (2001) recommends that the concentrations of Lys and Met as percentage of MP be 7.2 and $2.4 \%$, respectively. Sniffen et al. (2001) used a multiple regression approach and proposed optimal concentrations of $7.04 \%$ and $2.02 \%$ for Lys and Met, respectively. However, Schwab et al. (2003) concluded that under practical feeding conditions these concentrations are difficult to achieve and suggested practical recommendations of 6.6 and $2.2 \%$, respectively. When diets were evaluated using the NRC (2001) model, estimates of both Lys (5.33-6.38) and Met (1.72-1.75) as percentage of MP for all diets were lower than concentrations suggested by the NRC (2001). When considering the Lys:Met ratio, this ratio decreased from 3.7 for the $0 \%$ RFDG diet to 3.0 for the $30 \%$ RFDG diet (NRC, 2001).

\section{Intakes, Milk Yield, and Composition}

Previous studies have reported a similar type of response for DMI when feeding DDGS at concentrations up to $30 \%$ of the diet DM (Powers et al., 1995; Nichols et al., 1998; Liu et al., 2000; Anderson et al., 2006; Janicek et al., 2008). In the present study, intake of DM represented $3.24 \%$ of average $\mathrm{BW}$, which was less than predicted (3.43\% of BW) by the NRC (2001). Low intake may have resulted from high dietary NDF (Mertens, 1994), which averaged $41 \%$ of the diet DM. 
Table 10. Arterial plasma concentration of AA in dairy cows fed $0,10,20$, or $30 \%$ reduced-fat dried distillers grains with solubles (RFDG)

\begin{tabular}{|c|c|c|c|c|c|c|c|c|}
\hline $\mathrm{AA},{ }^{1} \mu M / \mathrm{L}$ & \multicolumn{4}{|c|}{ Dietary treatment, \% RFDG } & SEM & \multicolumn{3}{|c|}{ Contrast $(P \text {-value })^{2}$} \\
\hline \multicolumn{9}{|l|}{ EAA } \\
\hline His & 51.4 & 50.1 & 55.1 & 59.1 & 2.4 & 0.01 & 0.25 & 0.49 \\
\hline Ile & 118.3 & 110.0 & 103.8 & 91.8 & 6.8 & $<0.01$ & 0.78 & 0.78 \\
\hline Leu & 138.4 & 168.1 & 195.2 & 203.1 & 11.0 & $<0.01$ & 0.33 & 0.73 \\
\hline Thr & 66.7 & 64.5 & 64.4 & 65.4 & 5.1 & 0.87 & 0.75 & 0.97 \\
\hline Trp & 20.6 & 24.8 & 22.5 & 21.8 & 1.8 & 0.89 & 0.19 & 0.30 \\
\hline Val & 247.5 & 245.4 & 243.1 & 232.7 & 13.3 & 0.48 & 0.77 & 0.90 \\
\hline \multicolumn{9}{|l|}{ NEAA } \\
\hline Ala & 243.5 & 240.0 & 223.0 & 274.5 & 12.6 & 0.20 & 0.04 & 0.14 \\
\hline Asn & 35.0 & 32.6 & 36.4 & 37.8 & 3.1 & 0.38 & 0.51 & 0.51 \\
\hline Ser & 72.9 & 69.8 & 81.8 & 111.5 & 7.8 & $<0.01$ & 0.03 & 0.94 \\
\hline Tau & 44.4 & 40.7 & 42.1 & 47.5 & 3.7 & 0.53 & 0.22 & 0.93 \\
\hline Tyr & 45.1 & 53.2 & 64.0 & 79.0 & 4.4 & $<0.01$ & 0.43 & 0.94 \\
\hline EAA & 836 & 851 & 874 & 858 & 43 & 0.64 & 0.71 & 0.80 \\
\hline NEAA & 1,015 & 967 & 1,013 & 1,183 & 38 & $<0.01$ & 0.01 & 0.86 \\
\hline $\mathrm{BCAA}$ & 504 & 523 & 542 & 528 & 29 & 0.53 & 0.58 & 0.81 \\
\hline TAA & 1,851 & 1,819 & 1,887 & 2,041 & 71 & 0.05 & 0.18 & 0.96 \\
\hline
\end{tabular}

${ }^{1} \mathrm{EAA}=$ essential $\mathrm{AA} ; \mathrm{NEAA}=$ nonessential $\mathrm{AA} ; \mathrm{BCAA}=$ branched-chain $\mathrm{AA}($ Val, Ile, and Leu); TAA $=$ total AA $=\mathrm{EAA}+\mathrm{NEAA}$.

${ }^{2}$ Contrasts: $\mathrm{L}=$ linear, $\mathrm{Q}=$ quadratic, and $\mathrm{C}=$ cubic.

Milk production was similar in diets containing either RFDG or soybean-based proteins. In recent studies (Powers et al., 1995; Nichols et al., 1998; Anderson et al., 2006; Kleinschmit et al., 2006), an increase in milk production was observed following substitution of soybean meal with DDGS. In those studies, DDGS was included to supply both energy and protein by replacing part of the corn and protein sources. With this approach, energy supply and RUP may be greater than usually estimated. In this experiment, diets were theoretically formulated to be similar in RUP concentration. However, RUP might have increased in diets containing greater concentrations of RFDG. A predicted RUP value of $49.0 \%$ for RFDG was used to estimate dietary RUP concentration (NRC, 2001).

In most cases, inclusion of DDGS resulted in similar milk fat percentage when compared with soybean protein-based diets (Anderson et al., 2006), with a few reports indicating an increase in milk fat percentage (Clark and Armentano, 1993; Kleinschmit et al., 2006) and other reports indicating a decrease in milk fat percentage (Leonardi et al., 2005) in diets that contained $16.3 \%$ forage NDF. Rumen inert fat containing $85 \%$ saturated fat (Energy Booster 100, Milk Specialties, Dundee, IL) was added in graded amounts in an at- tempt to maintain similar EE; however, EE concentration increased with the inclusion of RFDG in the diet. The inclusion of saturated fats has given mixed results, from increased milk fat percentage (Elliott et al., 1996) to no increase in milk fat percentage (Moallem et al., 2007). Another reason for increased milk fat percentage may be related to the increased concentration of plasma Met being supplied by the RUP fraction in RFDG. In fact, the concentration of plasma Met increased almost 2 -fold when RFDG replaced all soybean protein-sources in the diets. Methionine supplied in a rumen-protected form (Overton et al., 1996), as a methionine hydroxyl analog (Huber et al., 1984), or infused postruminally (Varvikko et al., 1999) has been reported to increase milk fat concentration and yield. The mechanisms by which milk fat increases in response to an increased supply of Met are not well understood. Stimulation of choline synthesis from Met (Sharma and Erdman, 1988) or improvement in the synthesis of plasma lipoproteins, and hence increased transport of triglycerides to the mammary gland (Pullen et al., 1989), can increase milk fat synthesis. The increase in mammary plasma flow, although not significant, may give an indication of increased uptake of dietary fat precursors. Uptake of fat precursors, in contrast to the uptake of AA, seems to 
Table 11. Arteriovenous differences $(\mu \mathrm{M} / \mathrm{L})$ of AA in dairy cows fed $0,10,20$, or $30 \%$ reduced-fat dried distillers grains with solubles (RFDG)

\begin{tabular}{|c|c|c|c|c|c|c|c|c|}
\hline \multirow[b]{2}{*}{$\mathrm{AA},{ }^{1} \mu M / \mathrm{L}$} & \multicolumn{4}{|c|}{ Dietary treatment, \% RFDG } & \multirow[b]{2}{*}{ SEM } & \multicolumn{3}{|c|}{ Contrast $(P \text {-value })^{2}$} \\
\hline & 0 & 10 & 20 & 30 & & $\mathrm{~L}$ & $\mathrm{Q}$ & $\mathrm{C}$ \\
\hline \multicolumn{9}{|l|}{ EAA } \\
\hline Arg & 25.0 & 33.8 & 31.6 & 27.8 & 3.6 & 0.70 & 0.07 & 0.53 \\
\hline His & 13.1 & 12.3 & 11.0 & 11.6 & 1.6 & 0.42 & 0.63 & 0.71 \\
\hline Ile & 40.8 & 40.2 & 40.8 & 35.0 & 4.1 & 0.36 & 0.51 & 0.65 \\
\hline Leu & 58.3 & 64.4 & 65.9 & 67.1 & 7.0 & 0.40 & 0.74 & 0.90 \\
\hline Lys & 42.6 & 37.1 & 36.5 & 32.4 & 2.9 & 0.02 & 0.80 & 0.50 \\
\hline Met & 12.1 & 10.4 & 11.8 & 12.4 & 1.6 & 0.74 & 0.45 & 0.57 \\
\hline Phe & 18.9 & 19.7 & 18.6 & 19.0 & 2.3 & 0.93 & 0.93 & 0.73 \\
\hline Thr & 23.3 & 26.2 & 22.5 & 24.6 & 4.0 & 0.99 & 0.51 & 0.01 \\
\hline $\operatorname{Trp}$ & 5.1 & 5.0 & 4.8 & 2.2 & 2.0 & 0.33 & 0.52 & 0.78 \\
\hline Val & 52.4 & 53.7 & 48.7 & 51.4 & 6.6 & 0.80 & 0.91 & 0.63 \\
\hline \multicolumn{9}{|l|}{ NEAA } \\
\hline Ala & 29.3 & 27.9 & 7.7 & 13.0 & 7.8 & 0.05 & 0.65 & 0.19 \\
\hline Asn & 22.4 & 36.4 & 26.0 & 21.3 & 3.9 & 0.44 & 0.02 & 0.08 \\
\hline Asp & 3.5 & 3.1 & 2.8 & 2.4 & 0.7 & 0.29 & 0.97 & 0.90 \\
\hline Gln & 89.7 & 71.9 & 65.2 & 65.4 & 11.1 & 0.66 & 0.72 & 0.95 \\
\hline Glu & 20.1 & 23.5 & 20.5 & 24.1 & 3.9 & 0.59 & 0.99 & 0.44 \\
\hline Gly & 7.7 & 3.7 & 4.7 & 4.4 & 4.1 & 0.71 & 0.92 & 0.99 \\
\hline Pro & 6.5 & 6.2 & 4.7 & 4.4 & 8.8 & 0.71 & 0.99 & 0.92 \\
\hline Ser & 10.9 & 18.6 & 13.4 & 8.3 & 9.6 & $<0.01$ & $<0.01$ & 0.58 \\
\hline Tau & 1.9 & 1.2 & -2.4 & 2.3 & 1.5 & 0.73 & 0.07 & 0.09 \\
\hline Tyr & 18.3 & 20.7 & 16.8 & 14.0 & 2.5 & 0.12 & 0.46 & 0.42 \\
\hline EAA & 292 & 302 & 290 & 280 & 29 & 0.72 & 0.72 & 0.84 \\
\hline NEAA & 186 & 181 & 123 & 141 & 25 & 0.12 & 0.67 & 0.28 \\
\hline $\mathrm{BCAA}$ & 152 & 158 & 156 & 153 & 18 & 0.97 & 0.80 & 0.89 \\
\hline TAA & 478 & 484 & 412 & 420 & 51 & 0.31 & 0.98 & 0.49 \\
\hline
\end{tabular}

${ }^{1} \mathrm{EAA}=$ essential AA; NEAA = nonessential AA; BCAA = branched-chain AA (Val, Ile, and Leu); TAA = total AA = EAA + NEAA.

${ }^{2}$ Contrasts: $\mathrm{L}=$ linear, $\mathrm{Q}=$ quadratic, and $\mathrm{C}=$ cubic.

be regulated primarily by their arterial concentration (Nielsen and Jakobsen, 1994).

Milk protein is rarely affected when dairy cows are fed DDGS at concentrations less than $20 \%$ of the diet (DM basis). In contrast, this effect was noticeable when Owen and Larson (1991) fed 37\% DDGS of the diet (DM basis). In the present study, even though MP was fed in excess of requirements for all treatments, milk protein percentage responded in a quadratic manner, with values being highest for cows fed 10 and $20 \%$ RFDG and lowest for cows fed 0 and 30\% RFDG. Milk protein percentage was numerically equal for cows fed either the soybean-based control ( $0 \%$ RFDG) or the $30 \%$ RFDG diets. A decrease in milk protein percentage was previously reported when DDGS from older ethanol plants were used (Owen and Larson, 1991) and also recently by Kleinschmit et al. (2006), suggesting that both heat damage and Lys deficiency may cause a decrease in milk protein concentration. In this experiment, RFDG was the sole supplemental protein source when included at $30 \%$. At this inclusion rate, arterial concentration of Lys decreased noticeably, causing an apparent deficiency. In addition, Lys as percentage of MP was estimated to be $5.73 \%$ when RFDG was in- cluded at $30 \%$ of the diet DM. According to Sniffen et al. (2001), milk protein percentage is reduced when this value is less than 6.0 to $6.5 \%$ of MP. The deficiency in Lys was probably exacerbated because the $30 \%$ RFDG contained exclusively corn products with limited amounts of alfalfa hay. In other experiments, milk protein yield was not affected when alfalfa constituted the main forage or when DDGS was included at a lower concentration in the diet (Broderick et al., 1990; Powers et al., 1995; Nichols et al., 1998). Another possible explanation for the decrease in milk protein percentage at $30 \%$ DM inclusion of RFDG is a potential for RDP shortage. In fact, diets were formulated to contain $10.1 \%$ of RDP based on an estimated RUP value of $49.0 \%$ for RFDG (NRC, 2001). This might underestimate the actual RUP in RFDG and decrease RDP to values below $10.1 \%$ (as DM), creating potential for a deficiency in $\mathrm{N}$ available for microbial protein synthesis in the rumen (NRC, 2001).

Although energy balance calculations are approximate, they can be helpful in characterizing the energy status of the animal. A deficit in $\mathrm{NE}_{\mathrm{I}}$ reflected in a negative energy balance can limit milk protein synthesis. Oldham (1984) stated that the protein-energy 
Table 12. Extraction efficiency ${ }^{1}$ of AA in dairy cows fed reduced-fat dried distillers grains with solubles (RFDG)

\begin{tabular}{|c|c|c|c|c|c|c|c|c|}
\hline $\mathrm{AA},{ }^{2} \%$ & \multicolumn{4}{|c|}{ Dietary treatment, \% RFDG } & SEM & \multicolumn{3}{|c|}{ Contrast $(P \text {-value })^{3}$} \\
\hline \multicolumn{9}{|l|}{ EAA } \\
\hline His & 25.3 & 24.5 & 19.1 & 19.7 & 2.4 & 0.04 & 0.76 & 0.30 \\
\hline Ile & 34.9 & 36.5 & 39.2 & 38.0 & 3.0 & 0.39 & 0.35 & 0.51 \\
\hline Leu & 42.0 & 38.3 & 33.1 & 33.4 & 4.8 & 0.02 & 0.50 & 0.58 \\
\hline Thr & 34.8 & 44.4 & 34.5 & 34.6 & 6.8 & 0.88 & 0.52 & 0.38 \\
\hline Trp & 15.7 & 20.0 & 18.9 & 4.9 & 9.0 & $<0.01$ & $<0.01$ & 0.85 \\
\hline Val & 20.9 & 22.1 & 19.6 & 22.0 & 2.4 & 0.94 & 0.79 & 0.41 \\
\hline \multicolumn{9}{|l|}{ NEAA } \\
\hline Ala & 11.4 & 12.1 & 3.7 & 4.9 & 3.0 & 0.06 & 0.95 & 0.19 \\
\hline Asn & 22.4 & 36.4 & 31.6 & 21.3 & 4.9 & 0.71 & 0.01 & 0.53 \\
\hline Ser & 12.8 & 24.4 & 19.3 & 7.8 & 7.2 & 0.73 & 0.02 & 0.5 \\
\hline Tau & 4.0 & 2.7 & -5.8 & 3.7 & 3.7 & 0.57 & 0.13 & 0.11 \\
\hline Tyr & 41.1 & 37.1 & 24.3 & 18.1 & 3.5 & $<0.01$ & 0.76 & 0.33 \\
\hline EAA & 34.5 & 35.6 & 32.5 & 32.8 & 2.5 & 0.46 & 0.86 & 0.49 \\
\hline NEAA & 17.6 & 18.9 & 12.1 & 11.9 & 2.6 & 0.05 & 0.75 & 0.19 \\
\hline $\mathrm{BCAA}$ & 29.9 & 30.3 & 28.2 & 29.2 & 2.7 & 0.71 & 0.92 & 0.73 \\
\hline TAA & 38.8 & 42.2 & 35.1 & 31.9 & 3.6 & 0.09 & 0.35 & 0.36 \\
\hline
\end{tabular}

${ }^{1}$ Extraction efficiency $=$ arteriovenous difference/arterial concentration $\times 100$.

${ }^{2} \mathrm{EAA}=$ essential AA; NEAA = nonessential AA; BCAA = branched-chain AA (Val, Ile, and Leu); TAA = total AA = EAA + NEAA.

${ }^{3}$ Contrasts: $\mathrm{L}=$ linear, $\mathrm{Q}=$ quadratic, and $\mathrm{C}=$ cubic.

relationship plays a role in directing nutrients between body tissues and nutrient utilization by the mammary gland. Repartitioning of AA toward energy formation may have occurred at the expense of milk protein synthesis. Therefore, the decrease in milk protein percentage observed in the 30\% RFDG was likely amplified by the lack of energy in combination with the apparent deficiency in Lys.

The MUN response in this study agrees with previous research (Kleinschmit et al., 2006, Janicek et al., 2008). With the addition of RFDG in the diets, RDP may have decreased, causing MUN to decrease. Lower RDP in combination with potentially lower intestinal digestibility of the protein contained in RFDG compared with soybean sources could also explain the lower MUN in RFDG diets.

\section{Plasma Metabolites and Energy Balance}

The modest positive energy balance of cows indicates that energy availability was barely meeting requirements. This is supported by the tendency for a linear increase in apparent energy efficiency as RFDG increased in the diet. Cows fed the 30\% RFDG diet were estimated to be in slightly negative energy balance, most likely due to a combination of low $\mathrm{NE}_{\mathrm{I}}$ and higher energy requirements for milk synthesis. As discussed earlier, DMI was less $(-1.7 \mathrm{~kg} / \mathrm{d})$ than predicted (NRC, 2001).

A linear increase in plasma concentration of glucose was observed. Feeding DDGS has had no effect on molar percentage of ruminal propionate, the main precursor of glucose in ruminants (Nichols et al., 1998; Liu et al., 2000; Anderson et al., 2006; Kleinschmit et al., 2006). Contribution of AA to gluconeogenesis is usually small and might become vital when glucose demands are high such as during early lactation (Bell, 1995). As MP was supplied in excess of requirements $(14 \%$ above), increased arterial supply of glucogenic AA and NEAA with added RFDG may have resulted in large amounts of AA being available for gluconeogenesis. Changes in plasma cholesterol concentrations among dietary treatments were evident. The increase in plasma cholesterol was typically observed when supplemental fat was added to the basal diet (Palmquist and Conrad 1978; Abdelqader et al., 2009).

Plasma concentration of 3-methylhistidine can be used as indicator of body protein mobilization (Blum and Reding, 1984). Unchanged 3-methylhistidine con- 
Table 13. Mammary uptake ${ }^{1}$ of AA in dairy cows fed $0,10,20$, or $30 \%$ reduced-fat dried distillers grains with solubles (RFDG)

\begin{tabular}{|c|c|c|c|c|c|c|c|c|}
\hline $\mathrm{AA},{ }^{2} \mathrm{~g} / \mathrm{kg}$ of milk & \multicolumn{4}{|c|}{ Dietary treatment, \% RFDG } & SEM & \multicolumn{3}{|c|}{ Contrast $(P \text {-value })^{3}$} \\
\hline \multicolumn{9}{|l|}{$\overline{\mathrm{EAA}}$} \\
\hline His & 0.94 & 0.90 & 0.78 & 0.99 & 0.12 & 0.94 & 0.29 & 0.41 \\
\hline Ile & 2.44 & 2.46 & 2.68 & 2.54 & 0.29 & 0.67 & 0.78 & 0.66 \\
\hline Leu & 3.50 & 3.91 & 4.23 & 4.89 & 0.77 & 0.05 & 0.80 & 0.84 \\
\hline Thr & 1.32 & 1.48 & 1.39 & 1.77 & 0.27 & 0.30 & 0.66 & 0.50 \\
\hline Trp & 0.38 & 0.39 & 0.45 & 0.41 & 0.29 & 0.91 & 0.92 & 0.89 \\
\hline Val & 2.76 & 2.90 & 2.63 & 3.26 & 0.39 & 0.48 & 0.52 & 0.42 \\
\hline \multicolumn{9}{|l|}{ NEAA } \\
\hline Ala & 1.09 & 1.18 & 0.29 & 0.66 & 0.31 & 0.12 & 0.64 & 0.10 \\
\hline Asn & 0.56 & 0.72 & 0.68 & 0.63 & 0.14 & 0.82 & 0.40 & 0.65 \\
\hline Ser & 0.51 & 1.05 & 0.68 & 0.53 & 0.30 & 0.82 & 0.24 & 0.36 \\
\hline Tau & 0.08 & 0.01 & -0.16 & 0.04 & 0.13 & 0.58 & 0.24 & 0.35 \\
\hline Tyr & 1.49 & 1.58 & 1.40 & 1.30 & 0.17 & 0.37 & 0.60 & 0.66 \\
\hline EAA & 18.55 & 19.68 & 19.54 & 21.91 & 2.31 & 0.33 & 0.78 & 0.70 \\
\hline NEAA & 11.08 & 11.36 & 8.34 & 10.54 & 1.56 & 0.50 & 0.53 & 0.20 \\
\hline BCAA & 8.67 & 9.29 & 9.55 & 10.71 & 1.14 & 0.21 & 0.80 & 0.79 \\
\hline TAA & 29.63 & 31.05 & 27.89 & 32.46 & 3.65 & 0.74 & 0.65 & 0.42 \\
\hline
\end{tabular}

${ }^{1}$ Mammary uptake $=$ arteriovenous difference $\times$ mammary plasma flow.

${ }^{2} \mathrm{EAA}=$ essential AA; NEAA = nonessential AA; BCAA = branched-chain AA (Val, Ile, and Leu); TAA = total AA = EAA + NEAA.

${ }^{3}$ Contrasts: $\mathrm{L}=$ linear, $\mathrm{Q}=$ quadratic, and $\mathrm{C}=$ cubic.

centrations agreed with similar BW and BW change among treatments.

It is well known that MUN and PUN depend on the dietary $\mathrm{CP}$ intake in lactating dairy cows (Broderick and Clayton 1997), and that MUN mirrors changes in PUN. In the present study, dietary CP concentration was similar among treatments. Differences in ruminal degradability of the different treatment diets may explain changes in PUN. Rumen ammonia concentration was not measured in the present study; therefore, partitioning urea according to its origins is speculative. However, the lower PUN in RFDG diets may indicate 1) lower rumen ammonia concentration, or 2) lower postruminal digestibility of RUP, leading to N excretion primarily via feces.

\section{Plasma Amino Acids}

Estimates of MPF are comparable with values found in the literature when MPF was estimated using the Fick principle (Korhonen et al., 2000; Mackle et al., 2000). Plasma AA concentrations were similar to those reported in previous studies where DDGS were evaluated (Liu et al., 2000; Kleinschmit et al., 2006). Quantitative and qualitative changes in arterial concentrations of EAA when RFDG gradually replaced soybean-based protein may reflect differences in protein degradability and AA composition between both sources. It is well known that Lys is deficient when corn feedstuffs predominate in the diet (Guinard and Rulquin, 1995). Arterial Lys concentration was decreased when DDGS replaced soybean meal (Nichols et al., 1998; Kleinschmit et al., 2006) or when DDGS replaced a blend of various protein sources (Liu et al., 2000). The supply of His, Leu, Met, Trp, Tyr, Phe, Ala, and Gly in RFDG diets probably exceeded the animal's requirements for these AA, which was supported by the low extraction efficiency of these AA. A higher extraction efficiency of Lys may be an indication of a Lys deficiency in the diet containing $30 \%$ RFDG. Even though the extraction efficiency of Lys continued to increase and probably reached a maximum at 30\% RFDG inclusion, milk protein percentage decreased, which supports the suggestion of Lys as the first-limiting amino acid at this inclusion rate.

Despite alterations in arterial AA concentrations, the AV differences of most EAA were relatively constant. The lack of effect on AV difference for most EAA except Lys confirms that arterial concentrations alone do not 
regulate mammary uptake of $\mathrm{AA}$ and that the mammary gland is the major regulator of its own metabolic rate (Bequette et al., 1998). In agreement with Guinard and Rulquin (1995), Lys uptake, however, seems to be dependent on arterial supply. In accordance with other reports (Korhonen et al., 2000), the uptake of NEAA, with the exception of Tyr, was inconsistent and often less than their output in milk.

Extraction efficiency has been used to identify the order of limiting amino acids because no errors are involved in the estimation of MPF with extraction efficiency (Nichols et al., 1998). Based on AA extraction efficiency, the order of limiting AA was Lys, Met, and Arg for diets containing RFDG, except for the $30 \%$ RFDG, where Arg was second limiting and Met was third liming. In contrast, in cows fed the 0\% RFDG diet, Met was first limiting followed by Lys and Phe. Using the same measure to rank AA, the same ranking was reported for diets containing up to $20 \%$ DDGS, except that Phe was third limiting (Nichols et al., 1998; Liu et al., 2000).

Despite the apparent deficiency in Lys for RFDG diets, uptake to output ratio of Lys indicates that the net removal of this AA by the mammary gland exceeds its requirement for milk protein synthesis, suggesting other roles within the gland. Excess Lys could be oxidized in the mammary gland (Bequette et al., 1998; Mabjeesh et al., 2000) or be used to synthesize some NEAA (Lapierre et al., 2003). The latter situation is less likely to occur in RFDG diets, as the arterial supply of NEAA clearly exceeded the requirement.

Similarly, net removal of Arg by the mammary gland exceeded its requirement for milk synthesis. In addition, ranking AA according to their extraction efficiency revealed that Arg was third limiting in RFDG diets. Research to identify amino acids that may become limiting after Lys and Met is scarce. Among the potential limiting amino acids were Arg and His. When Arg was infused into the abomasum of Holstein steers, $\mathrm{N}$ retention increased (Ragland-Gray et al., 1997). In contrast, abomasal infusion of Arg did not affect milk production or milk composition of post-peak-lactation Holstein cows (Vicini et al., 1988). In the present study, the extraction efficiency of Arg exceeded values reported by Liu et al. (2000) and Nichols et al. (1998). This can be explained in part by the linear decrease in dietary concentration of Arg and the numerical increase in mammary uptake of Arg as RFDG increased in the diet. These results are further supported by the decrease in Orn concentration in plasma, suggesting that less catabolism of Arg occurred in diets containing RFDG. The excessive extraction of the BCAA is in agreement with previous reports (Bequette et al., 1996) and can probably be attributed to intramammary oxidation (Bequette et al., 1996).

\section{CONCLUSIONS}

Inclusion of RFDG up to $30 \%$ of the diet on a DM basis to mid-lactation Holsteins did not adversely affect milk production or DMI. It resulted in increased milk fat percentage and yield, higher plasma glucose concentrations, and lower MUN and PUN concentrations. Feeding RFDG up to $30 \%$ supported similar lactation performance as a soybean-based diet; however, amino acid balance may have been better at $20 \%$ inclusion of RFDG. Although lactation performance was maintained with feeding $30 \%$ RFDG, it is important to note the excess in feeding MP as a result of including high amounts of this co-product. This may represent a limitation in areas of intensive animal agriculture in which nutrient management plans require minimal nutrient discharge into the environment.

\section{ACKNOWLEDGMENTS}

The authors express appreciation to personnel at the South Dakota State University Dairy Teaching and Research Facility for the feeding and care of the animals. This research was supported by funds from VeraSun Energy (Brookings, SD), the South Dakota Agricultural Experiment Station (Brookings, SD), and USDA-ARS (agreement no. 58-5447-7-322).

\section{REFERENCES}

Abdelqader, M. M., A. R. Hippen, K. F. Kalscheur, D. J. Schingoethe, K. Karges, and M. L. Gibson. 2009. Evaluation of corn germ from ethanol production as an alternative fat source in dairy cow diets. J. Dairy Sci. 92:1023-1037.

Allain, C. C., L. S. Poon, C. S. Chan, W. Richmond, and P. C. Fu. 1974. Enzymatic determination of total serum cholesterol. Clin. Chem. 20:470-475.

Anderson, J. L., D. J. Schingoethe, K. F. Kalscheur, and A. R. Hippen. 2006. Evaluation of dried and wet distillers grains included at two concentrations in the diets of lactating dairy cows. J. Dairy Sci. $89: 3133-3142$.

AOAC. 2002. Official Methods of Analysis. 17th ed. Assoc. Off. Anal. Chem., Gaithersburg, MD.

Bell, A. W. 1995. Regulation of organic nutrient metabolism during transition from late pregnancy to early lactation. J. Anim. Sci. $73: 2804-2819$.

Bequette, B. J., F. R. C. Backwell, and L. A. Crompton. 1998. Current concepts of amino acid metabolism in the mammary gland of the lactating ruminant. J. Dairy Sci. 81:2540-2559.

Bequette, B. J., F. R. C. Backwell, J. C. MacRae, G. E. Lobley, L. A. Crompton, J. A. Metcalf, and J. D. Sutton. 1996. Effect of intravenous amino acid infusion on leucine oxidation across the mammary gland of the lactating goat. J. Dairy Sci. 79:22172224 .

Blum, J. W., and T. Reding. 1984. Variations of 3-methylhistidine in blood of dairy cows. J. Dairy Sci. 68:2580-2587. 
Broderick, G. A., and M. K. Clayton. 1997. A statistical evaluation of animal and nutritional factors influencing concentrations of milk urea nitrogen. J. Dairy Sci. 80:2964-2971.

Broderick, G. A., D. B. Ricker, and L. S. Driver. 1990. Expeller soybean meal and corn by-products versus solvent soybean meal for lactating dairy cows fed alfalfa silage as sole forage. J. Dairy Sci. 73:453-462.

Cant, J. P., E. J. DePeters, and R. L. Baldwin. 1993. Mammary amino acid utilization in dairy cows fed fat and its relationship to milk protein depression. J. Dairy Sci. 76:762-773.

Clark, J. H., H. R. Spires, and C. L. Davis. 1978. Uptake and metabolism of nitrogenous components by the lactating mammary gland. Fed. Proc. 37:1233-1238.

Clark, P. W., and L. E. Armentano. 1993. Effectiveness of neutral detergent fiber in whole cottonseed and dried distillers grains compared with alfalfa haylage. J. Dairy Sci. 76:2644-2650.

Elliott, J. P., J. K. Drackley, and D. J. Weigel. 1996. Digestibility and effects of hydrogenated palm fatty acid distillate in lactating dairy cows. J. Dairy Sci. 79:1031-1039.

Grunau, J. A., and J. M. Swiader. 1992. Chromatography of 99 amino acids and other ninhydrin-reactive compounds in the Pickering lithium gradient system. J. Chromatogr. A 594:165-171.

Guinard, J., and H. Rulquin. 1995. Effect of graded amounts of duodenal infusions of methionine on the mammary uptake of major milk precursors in dairy cows. J. Dairy Sci. 78:2196-2207.

Heinrichs, J., and P. Kononoff. 2002. Evaluating particle size of forages and TMRs using the new Penn State forage particle separator. Pennsylvania State University, Cooperative Extension. DAS 0242. http://dairyanimalscience.psu.edu/pdf/das0242.pdf. Accessed April 17, 2009.

Huber, J. T., R. S. Emery, W. G. Bergen, J. S. Liesman, L. Kung Jr., K. J. King, R. W. Gardner, and M. Checketts. 1984. Influences of methionine hydroxy analog on milk and milk fat production, blood serum lipids, and plasma amino acids. J. Dairy Sci. 67:25252531.

Jacobson, D. R., H. H. Van Horn, and C. J. Sniffen. 1970. Lactating ruminants. Fed. Proc. 29:35-40.

Janicek, B. N., P. J. Kononoff, A. M. Gehman, and P. H. Doane. 2008 The effect of feeding dried distillers grains plus solubles on milk production and excretion of urinary purine derivatives. J. Dairy Sci. 91:3544-3553.

Kalscheur, K. F. 2005. Impact of feeding distillers grains on milk fat, protein, and yield. Proc. Distillers Grains Technology Council, 9th Annual Symposium, Louisville, KY. DGTC, Louisville, KY.

Kleinschmit, D. H., D. J. Schingoethe, K. F. Kalscheur, and A. R. Hippen. 2006. Evaluation of various sources of corn dried distillers grains plus solubles for lactating dairy cattle. J. Dairy Sci. 89:4784-4794.

Kononoff, P. J., A. J. Heinrichs, and D. R. Buckmaster. 2003. Modification of Penn State forage and total mixed ration particle separator and the effects of moisture content on its measurements. J. Dairy Sci. 86:1858-1863.

Korhonen, M., A. Vanhatalo, T. Varvikko, and P. Huhtanen. 2000. Responses to graded postruminal doses of histidine in dairy cows fed grass silage diets. J. Dairy Sci. 83:2596-2608.

Lammers, B. P., D. R. Buckmaster, and A. J. Heinrichs. 1996. A simple method for the analysis of particle sizes of forages and total mixed rations. J. Dairy Sci. 79:922-928.

Lapierre, H., E. Milne, J. Renaud, and G. E. Lobley. 2003. Lysine utilization by the mammary gland. Pages $777-780$ in Progress in Research on Energy and Protein Metabolism. W. B. Souffrant and C. C. Metges, ed. EAAP Publication No. 109. Wageningen Academic Publishers, Wageningen, the Netherlands.

Leonardi, C., S. Bertics, and L. E. Armentano. 2005. Effect of increasing oil from distillers grains or corn oil on lactation performance. J. Dairy Sci. 88:2820-2827.

Littell, R. C., G. A. Milliken, W. W. Stroup, R. D. Wolfinger, and O. Schabenberger. 2006. SAS for Mixed Models. 2nd ed. SAS Institute, Cary, NC.
Liu, C., D. J. Schingoethe, and G. A. Stegeman. 2000. Corn distillers grains versus a blend of protein supplements with or without ruminally protected amino acids for lactating cows. J. Dairy Sci 83:2075-2084.

Mabjeesh, S. J., C. E. Kyle, J. C. MacRae, and B. J. Bequette. 2000. Lysine metabolism by the mammary gland of lactating goats at two stages of lactation. J. Dairy Sci. 83:996-1003.

Mackle, T. R., D. A. Dwyer, K. L. Ingvartsen, P. Y. Chouinard, D. A. Ross, and D. E. Bauman. 2000. Effects of insulin and postruminal supply of protein on use of amino acids by the mammary gland for milk protein synthesis. J. Dairy Sci. 83:93-105.

Mepham, T. B. 1982. Amino acid utilization by lactating mammary gland. J. Dairy Sci. 65:287-298.

Mertens, D. R. 1994. Regulation of forage intake. Pages 450-493 in Forage Quality, Evaluation, and Utilization. G. C. Fahey Jr., M. Collins, D. R. Mertens, and L. E. Moser, ed., Am. Soc. Agron., Crop Sci. Soc. Am., and Soil Sci. Soc. Am., Madison, WI.

Moallem, U., M. Katz, A. Arieli, and H. Lehrer. 2007. Effects of peripartum propylene glycol or dats differing in fatty acid profiles on feed intake, production, and plasma metabolites in dairy cows. J. Dairy Sci. 90:3846-3856

Mondina, A., G. Bongiovanni, S. Fumero, and L. Rossi. 1972. An improved method of plasma deproteination with sulphosalicylic acid for determining amino acids and related compounds. J. Chromatogr. A 74:255-263.

Nichols, J. R., D. J. Schingoethe, H. A. Maiga, M. J. Brouk, and M. S. Piepenbrink. 1998. Evaluation of corn distillers grains and ruminally protected lysine and methionine for lactating dairy cows. J. Dairy Sci. 81:482-491.

Nielsen, M. O., and K. Jakobsen. 1994. Changes in mammary uptake of free fatty acids, triglycerides, cholesterol and phospholipid in relation to milk synthesis during lactation in goats. Comp. Biochem. Physiol. Physiol. 109:857-867.

NRC. 2001. Nutrient Requirements of Dairy Cattle. 7th rev. ed. Natl Acad. Sci., Washington, DC.

Oldham, J. D. 1984. Protein-energy inter-relationships in dairy cows. J. Dairy Sci. 67:1090-1114

Overton, T. R., D. W. LaCount, T. M. Cicela, and J. H. Clark 1996. Evaluation of a ruminally protected methionine product for lactating dairy cows. J. Dairy Sci. 79:631-638.

Owen, F. G., and L. L. Larson. 1991. Corn distillers dried grains versus soybean meal in lactation diets. J. Dairy Sci. 74:972-979.

Palmquist, D. L., and H. R. Conrad. 1978. High fat rations for dairy cows: Effects on feed intake, milk and fat production, and plasma metabolites. J. Dairy Sci. 61:890-901.

Pickering, M. 1989. Ion-exchange chromatography of free amino acids. LC GC 7:484-490.

Powers, W. J., H. H. Van Horn, B. Harris Jr., and C. J. Wilcox. 1995. Effects of variable sources of distiller dried grain plus solubles on milk yield and composition. J. Dairy Sci. 78:388-396.

Pullen, D. L., D. L. Palmquist, and R. S. Emery. 1989. Effect on days of lactation and methionine hydroxy analog on incorporation of plasma fatty acids into plasma triglycerides. J. Dairy Sci. 72:4958.

Ragland-Gray, K. K., H. E. Amos, M. A. McCann, C. C. Williams, J. L. Sartin, C. R. Barb, and F. M. Kautz. 1997. Nitrogen metabolism and hormonal responses of steers fed wheat silage and infused with amino acids or casein. J. Anim. Sci. 75:3038-3045.

RFA. 2009. 2009 Ethanol industry outlook. http://www.ethanolrfa org/objects/pdf/outlook/RFA_Outlook_2009.pdf. Accessed Aug. 12,2009

Robertson, J. B., and P. J. Van Soest. 1981. The detergent system of analysis and its application to human foods. Pages 123-158 in The Analysis of Dietary Fiber in Food. W. P. T. James and O. Theander, ed. Marcel Dekker Inc., New York, NY.

SAS Institute. 2001. SAS User's Guide. Statistics, Version 9.01 ed SAS Institute, Inc., Cary, NC.

Schwab, C. G., R. S. Ordway, and N. L. Whitehouse. 2003. Amino acid balancing in the context of MP and RUP requirements. Pages 25- 
34 in Proc. Four-State Appl. Dairy Nutr. Manage. Conf., Lacrosse, WI. Midwest Plan Service, Iowa State University, Ames.

Sharma, B. K., and R. A. Erdman. 1988. Abomasal infusion of choline and methionine with or without 2-amino-2-methyl-1-propanol for lactating dairy cows. J. Dairy Sci. 71:2406-2411.

Sniffen, C. J., W. H. Chalupa, T. Ueda, H. Suzuki, I. Shinzato, T. Fujieda, W. Julien, L. Rode, P. Robinson, J. Harrison, A. Freeden, and J. Nocek. 2001. Amino acid nutrition of the lactation cow. Pages 188-197 in Proc. Cornell Nutr. Conf. Feed Manufact. Rochester, NY.

Spiehs, M. J., M. H. Whiteny, and G. C. Shurson. 2002. Nutrient database for distillers dried grains with solubles produced from new ethanol plants in Minnesota and South Dakota. J. Anim. Sci. 80:2639-2645.

Trinder, P. 1969. Determination of glucose in blood using glucose oxidase with an alternative oxygen acceptor. Ann. Clin. Biochem. $6: 24-27$.

Van Soest, P. J., J. B. Robertson, and B. A. Lewis. 1991. Methods for dietary fiber, neutral detergent fiber, and nonstarch polysaccharides in relation to animal nutrition. J. Dairy Sci. 74:3583-3597.
Varvikko, T., A. Vanhatalo, T. Jalava, and P. Huhtanen. 1999. Lactation and metabolic responses to graded abomasal doses of methionine and lysine in cows fed grass silage diets. J. Dairy Sci. 82:2659-2673.

Vicini, J. L., J. H. Clark, W. L. Hurley, and J. M. Bahr. 1988. Effects of abomasal or intravenous administration of arginine on milk production, milk composition, and concentrations of somatotropin and insulin in plasma of dairy cows. J. Dairy Sci. 71:658-665.

Wildman, E. E., G. M. Jones, P. E. Wagner, R. L. Boman, H. F. Troutt Jr., and T. N. Lesch. 1982. A dairy cow body condition scoring system and its relationship to standard production characteristics. J. Dairy Sci. 65:495-501.

Williamson, D. H., J. Mellanby, and H. A. Krebs. 1962. Enzymatic determination of $\mathrm{D}(-) \beta$-hydroxybutyrate and acetoacetic acid in blood. Biochem. J. 82:90-96. 